\title{
Genetic Characterization of the "Chusca Lojana", a Creole Goat Reared in Ecuador, and Its Relationship with Other Goat Breeds
}

\author{
Lenin Aguirre-Riofrio ${ }^{1, *(\mathbb{D}}$, Teddy Maza-Tandazo ${ }^{1}$, Manuel Quezada-Padilla ${ }^{1}$, \\ Oscar Albito-Balcazar ${ }^{1}$, Alex Flores-Gonzalez ${ }^{2}$, Osvaldo Camacho-Enriquez ${ }^{2}$, \\ Amparo Martinez-Martinez ${ }^{3}$, ${ }^{\text {, BioGoat Consortium }}{ }^{4}$ and Juan Vicente Delgado-Bermejo ${ }^{3}$ \\ 1 Agricultural Faculty, Veterinary Medicine and Zootechnics School, National University of Loja, Loja 110110, \\ Ecuador; temata1@hotmail.com (T.M.-T.); manuel.quezada@unl.edu.ec (M.Q.-P.); \\ oscar.albito@unl.edu.ec (O.A.-B.) \\ 2 Graduation Students in Veterinary Medicine and Zootechnics, National University of Loja, Zapotillo 110901, \\ Ecuador; afloresg@mag.gob.ec (A.F.-G); vladimirenrriquez@hotmail.com (O.C.-E.) \\ 3 Department of Genetics, University of Cordoba, 14014 Cordoba, Spain; \\ amparomartinezuco@gmail.com (A.M.-M.); id1debej@uco.es (J.V.D.-B.) \\ 4 Latin American Goat Biodiversity Project, Department of Genetics, University of Cordoba, 14014 Cordoba, \\ Spain; ib2mamaa@uco.es \\ * Correspondence: edgar.aguirre@unl.edu.ec; Tel.: +593-986448562
}

Received: 2 April 2020; Accepted: 26 May 2020; Published: 12 June 2020

check for updates

Simple Summary: An individual from a population presents a series of characteristics that differ from the rest and that increase as the kinship relationships are lower; this leads to the fact that two populations that stop exchanging genetic material through mating eventually come to present characters common to all members of each, but different between the two. This was what happened with the animal populations brought to America more than 500 years ago from the Iberian Peninsula in the colonization period, resulting in Creole populations that inhabit the harshest environments of our immense geography. The Creole goat "Chusca Lojana" has adapted to live in the dry forest region of Southern Ecuador, where environmental conditions are warm-dry, with sparse vegetation and a rather irregular topography. In the present study, the intra-breed genetic diversity of this goat is analyzed as well as its genetic relationships with other breeds. Significant $\mathrm{F}_{\mathrm{IS}}$ and intra-breed structure show that there is some heterogeneity and structure within the breed. However, inter-breed structure results underline that this breed is differentiated from other Creole breeds, because crossbreeding with other breeds was not detected; therefore, we must take advantage of this valuable genetic resource, and ensure its conservation and selection.

Abstract: The largest population of goats (62\%) in Ecuador is in the dry forest region in the south of the country. A Creole goat, named "Chusca Lojana", has adapted to the dry forest region where environmental conditions are warm-dry, with sparse vegetation. Knowledge of the genetic information of the Creole goat is important to determine intra-racial diversity, the degree of genetic distance among other breeds of goats, and the possible substructure of the population, which is valuable for the conservation of such a species' genetic resources. A total of 145 samples of the Creole goat was taken from the four biotypes previously identified. Genetic analyses were performed using 38 microsatellites recommended for studies of goat genetic diversity (FAO-ISAG). The results of within-breed genetic diversity showed a mean number of alleles per locus (MNA) of 8 , an effective number of alleles (Ae) of 4.3, an expected heterozygosity (He) of 0.71 , an observed heterozygosity (Ho) of 0.63 , polymorphic information content (PIC) of 0.67 , and an $\mathrm{F}_{\text {IS }}$ value of 0.11 . Between-breed genetic diversity among 43 goat populations (native of Spain, American Creole, Europeans, and Africans) showed the following values: $\mathrm{F}_{\mathrm{IS}}=0.087, \mathrm{~F}_{\mathrm{IT}}=0.176$, and $\mathrm{F}_{\mathrm{ST}}=0.098$. Regarding the analysis 
of the population structure, the results showed that the Creole Chusca Lojana goat population is homogeneous and no genetic separation was observed between the different biotypes $\left(\mathrm{F}_{\mathrm{ST}}=0.0073\right)$. In conclusion, the Chusca Lojana goat has a high genetic diversity, without exhibiting a genetic substructure. Therefore, it should be considered as a distinct population because crossbreeding with other breeds was not detected.

Keywords: Capra hircus; biodiversity; genetic resources; conservation; microsatellites markers

\section{Introduction}

Biodiversity and abiotic factors are responsible for maintaining the balance and stability of ecosystems. According to [1], biodiversity is the sum of all living organisms on earth, comprising the wide variety of species, ecosystems, and ecological processes that make up our planet. Therefore, biological diversity in a particular place, region, or country must be considered as a key resource, not only for its genetic heritage, but also for its ecological, social, economic, scientific, educational, cultural, and aesthetic values.

In the last two decades, however, such genetic heritage has been jeopardized and more than one million species have become endangered [2,3]. Regarding livestock species, some of the local breeds $(26 \%)$ of animals in the world are currently endangered, $7 \%$ of which has already disappeared only in the last 20 years [4]. Replacement of local breeds by exotic ones may involve an increase in the degree of inbreeding in these populations [5,6], with a subsequent decrease in effective population size [7] and a decline in resistance and resilience to environmental changes.

Goat farming is of great significance for the economy of rural populations worldwide, especially in developing countries due to the rusticity of goats [6,8]. Goats are capable of taking advantage of low-quality natural resources that are unsuitable to other species [9]. This is the case of the Creole goat "Chusca Lojana", which has adapted to the Dry Forest region in the Loja Province of Ecuador, an environment with a pronounced dry season during parts of the year and limited natural resources. Against this background, the purpose of the present study was to characterize the Creole Chusca Lojana goat genetically for future genetic conservation, use, and management, being a priority task because this resource represents a genetic, cultural, social, and economic heritage for this region.

\section{Materials and Methods}

\subsection{Samples and DNA Extraction}

Hair samples were obtained from 145 Chusca Lojana goats of four different biotypes, the same ones that differ from each other in the size and shape of the ears ("oreja corta y doblada", "oreja de leon", and "oreja torneada" biotypes) and in the absence of horns ("muco" biotype). Sampled individuals belonged to different herds and locations and kinship was minimized, so genetic variability of sampling was ensured. Samples were collected in paper envelopes with individual information and stored at room temperature until genetic analyses were performed at the Laboratory of Applied Molecular Genetics of the University of Cordoba, Spain. Sampling was carried out by qualified veterinarians during routine technical assistance, so the approval of an animal ethics and welfare committee for biological sampling collection was not required. The genomic DNA of the hair follicle samples was extracted according to the methodology described by [10].

\subsection{Genotyping Using STR Markers}

Thirty-eight microsatellites were used, including the thirty recommended by the FAO/ISAG (Food and Agriculture Organization of the United Nations/International Society of Animal Genetics) for genetic diversity studies in goat species. The microsatellites included were BM1258, BM1329, BM1818, 
BM6506, BM6526, BM8125, CSRD247, CSRM60, CSSM66, ETH010, ETH225, HAUT27, HSC, ILSTS008, ILSTS011, ILSTS019, ILSTS030, ILSTS087, INRA005, INRA006, INRA023, INRA063, INRA172, MAF065, MAF209, McM527, MM12, OarFCB011, OarFCB020, OarFCB048, OarFCB304, SPS115, SRCRSP05, SRCRSP08, SRCRSP23, SRCRSP24, TGLA053, and TGLA122. After amplification by the polymerase chain reaction (PCR) technique, size separation of the amplified fragments was carried out by polyacrylamide gel electrophoresis in an ABI 3130XL automatic sequencer by means of Genescan ${ }^{\circledR}$ 400HD ROX Size Standard (Fisher Scientific, Madrid, Spain). Fragment analysis and allelic typing were performed using Genescan Analysis ${ }^{\circledR}$ 3.1.2 (Fisher Scientific, Madrid, Spain) and Genotyper ${ }^{\circledR}$ 2.5.2 software (Fisher Scientific, Madrid, Spain), respectively (Figure S1).

\subsection{Genetic Diversity Within-Breed}

The MICROSATELLITE TOOLKIT software for Excel [11] was used to determine the average number of alleles per locus (MNA), expected allelic frequencies (He), observed heterozygosis (Ho), and polymorphic information content (PIC). The effective number of alleles was calculated with the PopGene program [12]. The $\mathrm{F}_{\text {IS }}$ fixation index values with a $95 \%$ confidence interval were calculated with the GENETIX v software 4.05 [13]. The Hardy-Weinberg (HW) equilibrium test was performed using the GENEPOP v program 3.1c [14], which applies Fisher's exact test using the Monte Carlo Markov chain method [15] and Bonferroni correction.

\subsection{Genetic Diversity Inter-Breed}

To obtain the genetic differentiation, structure, and distance information data of the Chusca Lojana goat was compared with data of other 42 goat populations worldwide, which included some native Creole breeds from Spain, Europe, America, and Africa (Table 1). Data on worldwide breeds were collected from the online database of the Laboratory of Applied Molecular Genetics and the BioGoat Consortium (https://biogoat.jimdo.com/razas-breeds/).

Wright's F statistics, namely $\mathrm{F}_{\mathrm{IT}}, \mathrm{F}_{\mathrm{ST}}$, and $\mathrm{F}_{\mathrm{IS}}$ [16], were calculated using GENETIX software [13]. A Factorial Correspondence Analysis was performed with the same program. The Reynolds' genetic distance [17] was determined using the POPULATIONS software [18]. With the distance values obtained, a Neighbor-Net was carried out using the SPLITSTREE program [19] to graphically represent the genetic relationships among the breeds. Table 1 shows the compared goat populations, their origin, and the number of samples analyzed for each population, in which 24 microsatellites common to all breeds were identified.

\subsection{Genetic Structure of Chusca Lojana Goat}

The genetic distances between individuals ( $\left.\mathrm{D}_{\mathrm{SA}}\right)$ were calculated [20], and a dendrogram was elaborated using the TREEVIEW program [21]. An analysis of the substructure of the Creole Chusca Lojana goat was also carried based on a Bayesian algorithm with the STRUCTURE v 2.1 program [22], which uses a model based on the Monte Carlo Markov chain method to estimate the consequent distribution of the admixture proportion of each individual (q). The analysis was performed using a 100,000 burn-in period followed by 300,000 iterations of Monte Carlo repeating each run 10 times.

Table 1. Populations studied, acronym, origin, and number of samples analyzed for each population.

\begin{tabular}{ccccc}
\hline & Breed/Population & Acronym & Origin & n \\
\hline 1 & Chusca Lojana & LOJ & Ecuador & 145 \\
2 & Galapagos goat & GAG & Galapagos Islands (Ecuador) & 24 \\
3 & Spanish goat & SPA & USA & 64 \\
4 & Myotonic & MYO & USA & 43 \\
5 & Mexicana & MEX & Mexico & 70 \\
6 & Creole from Cuba & CUB & Cuba & 40 \\
7 & Creole from Colombia & COL & Colombia & 24 \\
\hline
\end{tabular}


Table 1. Cont.

\begin{tabular}{|c|c|c|c|c|}
\hline & Breed/Population & Acronym & Origin & $\mathbf{n}$ \\
\hline 8 & Creole from Venezuela & VEN & Venezuela & 45 \\
\hline 9 & Creole from Perú & PER & Peru & 61 \\
\hline 10 & Moxotó & MOX & Brazil & 40 \\
\hline 11 & Creole from Bolivia & BOL & Bolivia & 40 \\
\hline 12 & Creole from Paraguay & PGY & Paraguay & 84 \\
\hline 13 & North-east creole & NEA & Argentina & 40 \\
\hline 14 & Neuquina & NUQ & Argentina & 51 \\
\hline 15 & Blanca de Rasquera & RAS & Spain & 56 \\
\hline 16 & Retinta & RET & Spain & 15 \\
\hline 17 & Verata & VERA & Spain & 30 \\
\hline 18 & Blanca Andaluza & BLANCA & Spain & 40 \\
\hline 19 & Celtibérica & CELTIB & Spain & 40 \\
\hline 20 & Malagueña & MALAG & Spain & 40 \\
\hline 21 & Murciano-Granadina & MG & Spain & 40 \\
\hline 22 & Florida & FLO & Spain & 50 \\
\hline 23 & Payoya & PAY & Spain & 36 \\
\hline 24 & Negra Serrana & SER & Spain & 42 \\
\hline 25 & Pitiusa & IB & Islas Baleares (Spain) & 79 \\
\hline 26 & Mallorquina & MALL & Islas Baleares (Spain) & 70 \\
\hline 27 & Majorera & MFV & Islas Canarias (Spain) & 64 \\
\hline 28 & Palmera & PAL & Islas Canarias (Spain) & 32 \\
\hline 29 & Tinerfeña & TF2 & Islas Canarias (Spain) & 70 \\
\hline 30 & Cabo Verde & CVERDE & Cabo Verde & 37 \\
\hline 31 & Barki & BARKI & Egypt & 44 \\
\hline 32 & Baladi & BALADI & Egypt & 31 \\
\hline 33 & Saidi & SAIDI & Egypt & 34 \\
\hline 34 & Morocco & MOR & Marruecos & 24 \\
\hline 35 & Tunisian Local Goat & TU & Tunisia & 58 \\
\hline 36 & Maradi & MARADI & Nigeria & 47 \\
\hline 37 & West African Dwarf & WAD & Nigeria & 52 \\
\hline 38 & Sahel & SAHEL & Nigeria & 46 \\
\hline 39 & Kalahari Goat & KAL & South Africa & 47 \\
\hline 40 & Boer & BOER & South Africa & 46 \\
\hline 41 & Saanen & SAAN & International & 36 \\
\hline 42 & Alpina & ALP & International & 37 \\
\hline 43 & Anglo-Nubiana & ANG & International & 41 \\
\hline
\end{tabular}

\section{Results}

\subsection{Genetic Diversity Within-Breed}

Shown in Table 2 are the values obtained for expected heterozygosity (He), observed heterozygosity (Ho), polymorphic information content (PIC), the $\mathrm{F}_{\mathrm{IS}}$ values with their standard deviations, and the deviated markers of the Hardy-Weinberg equilibrium. Given the PIC values obtained, most markers were informative (PIC > 0.5). After Bonferroni correction, only the INRA023 and SRCRSP24 markers were unstable compared with the Hardy-Weinberg equilibrium of the population. Only the INRA005 and SPS115 markers showed a homozygous defect, but their $\mathrm{F}_{\mathrm{IS}}$ values were not significant. Half of the microsatellites $(n=19)$ showed a significant excess of homozygosity, and the other microsatellites $(n=19)$ displayed $\mathrm{F}_{\mathrm{IS}}$ values that were not significantly different from 0.

The mean number of alleles (MNA) is an indicator of the genetic variability within populations. The MNA is 8.26 in the Chusca Lojana goat, and with an average Ae value of 4.25. We assessed the genetic diversity within a population by calculating the proportion of heterozygous individuals or heterozygosity. In Table 2, the values of expected mean heterozygosity $(\mathrm{He}=0.706)$ and mean heterozygosity by direct count $(\mathrm{Ho}=0.629)$ are shown. The value of $\mathrm{F}_{\mathrm{IS}}$ with a $95 \%$ confidence interval 
and 1000 randomizations was significant $\left(\mathrm{F}_{\mathrm{IS}}=0.1099(0.08773-0.12549)\right)$, which indicates that the population could deviate from the Hardy-Weinberg equilibrium.

Table 2. Genetic results of the "Chusca Lojana" goat: microsatellites, mean number of alleles (MNA), effective number of alleles (Ae), expected heterozygosity (He), observed heterozygosity (Ho), polymorphic information content (PIC), $\mathrm{F}_{\text {IS }}$ values and confidence interval, and Hardy-Weinberg equilibrium (HWE) deviations.

\begin{tabular}{|c|c|c|c|c|c|c|c|c|}
\hline Microsatellites & MNA & Ae & $\mathrm{He}$ & Ho & PIC & FIS & FIS IC & HWEd \\
\hline BM1258 & 12 & 5.04 & 0.804 & 0.755 & 0.78 & 0.06116 & $(-0.02427-0.13910)$ & NS \\
\hline BM1329 & 8 & 5.99 & 0.836 & 0.741 & 0.81 & 0.11373 & $(-0.02560-0.19802)$ & NS \\
\hline BM1818 & 9 & 4.65 & 0.788 & 0.746 & 0.76 & 0.05246 & $(-0.02859-0.13614)$ & NS \\
\hline BM6506 & 11 & 6.73 & 0.855 & 0.746 & 0.84 & 0.12696 & $(0.04177-0.20820)$ & NS \\
\hline$B M 6526$ & 9 & 5.65 & 0.826 & 0.819 & 0.8 & 0.008 & $(-0.06846-0.07866)$ & NS \\
\hline BM8125 & 7 & 2.35 & 0.576 & 0.559 & 0.53 & 0.03099 & $(-0.08580-0.14336)$ & NS \\
\hline CSRD247 & 7 & 4.61 & 0.786 & 0.729 & 0.76 & 0.07246 & $(-0.01127-0.15292)$ & NS \\
\hline CSRM60 & 8 & 4.43 & 0.777 & 0.748 & 0.74 & 0.03741 & $(-0.05035-0.12679)$ & NS \\
\hline CSSM66 & 20 & 7.02 & 0.861 & 0.69 & 0.84 & 0.1987 & $(0.11256-0.27766)$ & NS \\
\hline ETH010 & 4 & 2.06 & 0.516 & 0.434 & 0.44 & 0.15805 & $(0.00882-0.30514)$ & NS \\
\hline ETH225 & 6 & 1.30 & 0.233 & 0.214 & 0.22 & 0.08139 & $(-0.06547-0.23836)$ & NS \\
\hline HAUT27 & 7 & 3.68 & 0.731 & 0.622 & 0.7 & 0.14921 & $(0.05547-0.23469)$ & NS \\
\hline HSC & 14 & 8.42 & 0.885 & 0.789 & 0.87 & 0.10785 & $(0.03307-0.18731)$ & NS \\
\hline ILSTS008 & 3 & 1.60 & 0.375 & 0.352 & 0.34 & 0.06315 & $(-0.06421-0.19046)$ & NS \\
\hline ILSTS011 & 8 & 1.95 & 0.49 & 0.469 & 0.43 & 0.04338 & $(-0.08673-0.17046)$ & NS \\
\hline ILSTS019 & 7 & 4.42 & 0.776 & 0.681 & 0.74 & 0.12382 & $(0.02715-0.22251)$ & NS \\
\hline ILSTS030 & 9 & 6.01 & 0.837 & 0.667 & 0.81 & 0.20378 & (0.10995-0.29227) & NS \\
\hline ILSTS087 & 7 & 3.16 & 0.686 & 0.667 & 0.64 & 0.02767 & $(-0.06163-0.11632)$ & NS \\
\hline INRA005 & 4 & 2.58 & 0.615 & 0.621 & 0.55 & -0.00962 & $(-0.12535-0.09767)$ & NS \\
\hline INRA006 & 9 & 7.63 & 0.872 & 0.671 & 0.86 & 0.23073 & $(0.13451-0.31479)$ & NS \\
\hline INRA023 & 7 & 5.73 & 0.828 & 0.507 & 0.8 & 0.38867 & $(0.28331-0.48339)$ & $* * *$ \\
\hline INRA063 & 5 & 2.50 & 0.601 & 0.462 & 0.52 & 0.23224 & $(0.10057-0.35608)$ & NS \\
\hline INRA172 & 7 & 3.78 & 0.738 & 0.655 & 0.69 & 0.11342 & $(0.01843-0.20403)$ & NS \\
\hline MAF065 & 10 & 4.28 & 0.769 & 0.664 & 0.74 & 0.13723 & $(0.03830-0.23089)$ & NS \\
\hline MAF209 & 2 & 1.52 & 0.341 & 0.269 & 0.28 & 0.21245 & $(0.02267-0.38747)$ & NS \\
\hline McM527 & 9 & 4.20 & 0.765 & 0.669 & 0.73 & 0.12542 & (0.01993-0.21898) & NS \\
\hline MM12 & 14 & 7.46 & 0.869 & 0.813 & 0.85 & 0.06528 & $(-0.00962-0.13071)$ & NS \\
\hline OarFCB011 & 10 & 4.58 & 0.784 & 0.734 & 0.75 & 0.064 & $(-0.02090-0.15133)$ & NS \\
\hline OarFCB020 & 6 & 1.70 & 0.414 & 0.372 & 0.38 & 0.0999 & $(-0.04615-0.23000)$ & NS \\
\hline OarFCB048 & 11 & 4.69 & 0.789 & 0.746 & 0.76 & 0.05456 & $(-0.02320-0.13311)$ & NS \\
\hline OarFCB304 & 12 & 4.77 & 0.793 & 0.738 & 0.76 & 0.06993 & $(-0.01207-0.15543)$ & NS \\
\hline SPS115 & 6 & 1.93 & 0.488 & 0.549 & 0.4 & -0.13716 & $(-0.27617-0.00121)$ & NS \\
\hline SRCRSP05 & 7 & 5.47 & 0.82 & 0.759 & 0.79 & 0.07493 & $(-0.01091-0.15903)$ & NS \\
\hline SRCRSP08 & 6 & 5.07 & 0.772 & 0.643 & 0.73 & 0.16705 & $(0.05626-0.26468)$ & NS \\
\hline SRCRSP23 & 11 & 3.69 & 0.805 & 0.722 & 0.78 & 0.10356 & $(0.01086-0.18899)$ & NS \\
\hline SRCRSP24 & 8 & 4.33 & 0.732 & 0.558 & 0.69 & 0.23787 & $(0.11786-0.33931)$ & $* *$ \\
\hline TGLA053 & 7 & 3.58 & 0.723 & 0.722 & 0.68 & 0.00138 & $(-0.09825-0.08853)$ & NS \\
\hline \multirow[t]{2}{*}{ TGLA122 } & 7 & 3.09 & 0.679 & 0.587 & 0.64 & 0.13537 & $(0.02766-0.23688)$ & NS \\
\hline & 8 & 4.3 & 0.71 & 0.63 & 0.67 & 0,10986 & $(0.08773-0.12549)$ & \\
\hline
\end{tabular}

NS: Not Significant; ${ }^{* *} p<0.01 ;{ }^{* * *} p>0.001$.

\subsection{Genetic Structure of the Chusca Lojana Goat}

To make a preliminary assessment of the population's homogeneity, a tree diagram of the genetic distances between individuals was designed (Figure 1), in which the individuals are grouped with color codes according to their genetic proximity. There is no clear grouping of the individuals by biotypes. This lack of genetic separation is supported by a very low genetic differentiation among them $\left(\mathrm{F}_{\mathrm{ST}}=0.0073\right)$. 


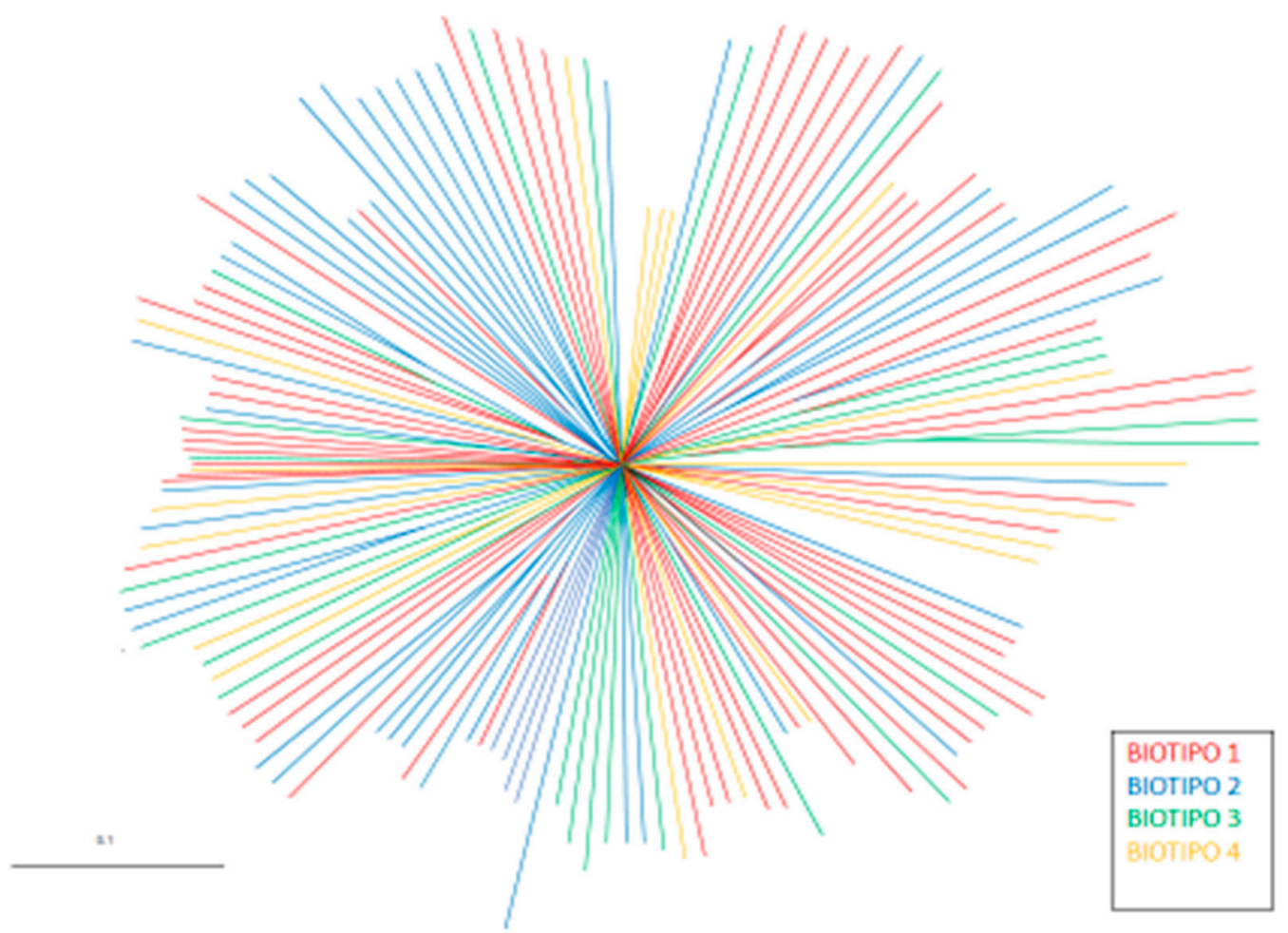

Figure 1. Tree diagram of the individual genetic distances $\left(\mathrm{D}_{\mathrm{SA}}\right)$.

A more complex analysis of the population structure was also carried out using STRUCTURE v. 2.1. This software [22] allowed the calculation of the admixture proportions of each individual (q). The mean distribution represents an estimation of the proportion of the genome that every individual displayed in relation to the parental population. A grouping analysis of the individuals was also carried out with a different number of clusters $(K)$ representing the assumed number of populations. An admixture model was designed using the above software, in which each individual could contain in its genome a different percentage of the ancestral populations from which it might come. When only the Chusca Lojana goat was considered, heterogeneous genetic structure was detected in the four biotypes (Figure 2).

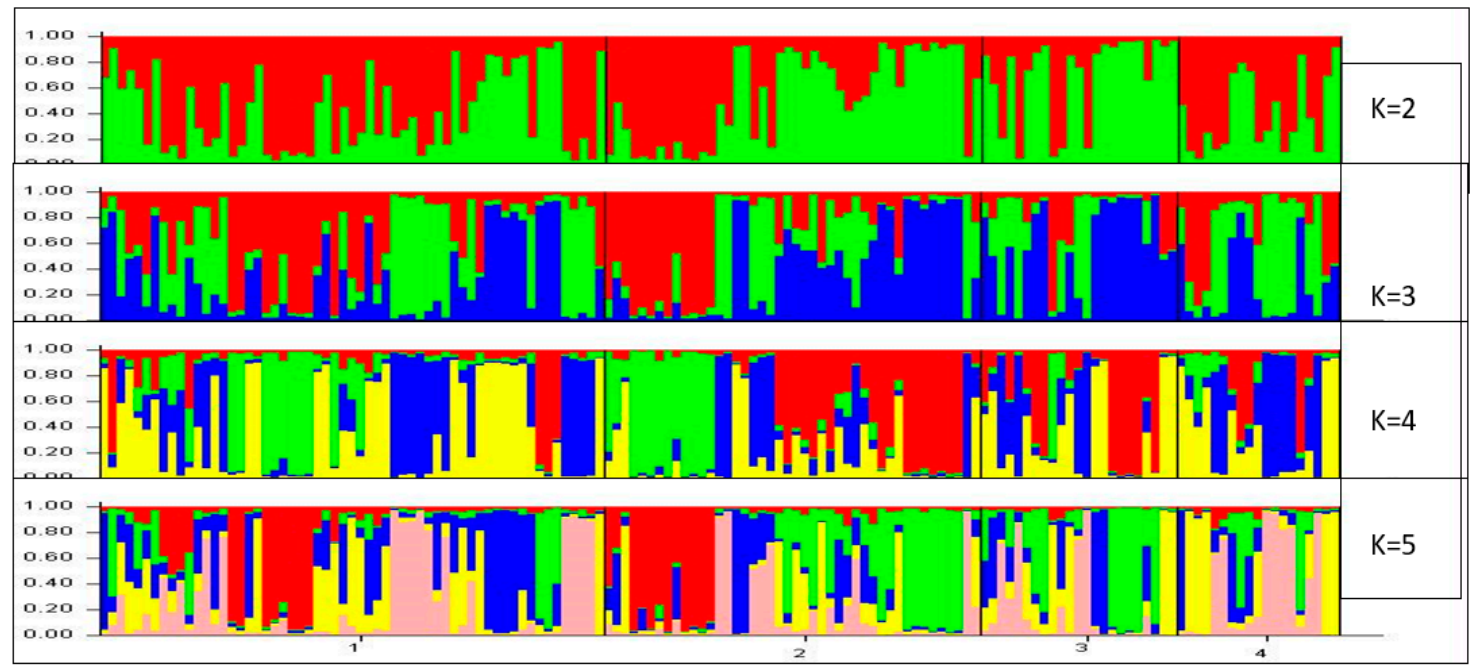

Figure 2. Genetic structure of the Chusca Lojana. Cluster diagram of the population for K ranging from 2 to 5 . 


\subsection{Genetic Diversity Inter-Breed}

The genetic differentiation among the 43 populations of goats included in the present study was high, with the following statistical values for $F$ : $F_{I S}=0.0871(0.065-0.116), \mathrm{F}_{\mathrm{IT}}=0.176(0.154-0.205)$, and $\mathrm{F}_{\mathrm{ST}}=0.0978(0.089-0.108)$.

The results of the Correspondence Factor Analysis (Figure 3) show that the South African breeds (Axis 1) and the Egyptian Barki breed (Axis 2) are different from the others. The Chusca Lojana goat, which is represented by a yellow circle, is related to other Creole breeds.
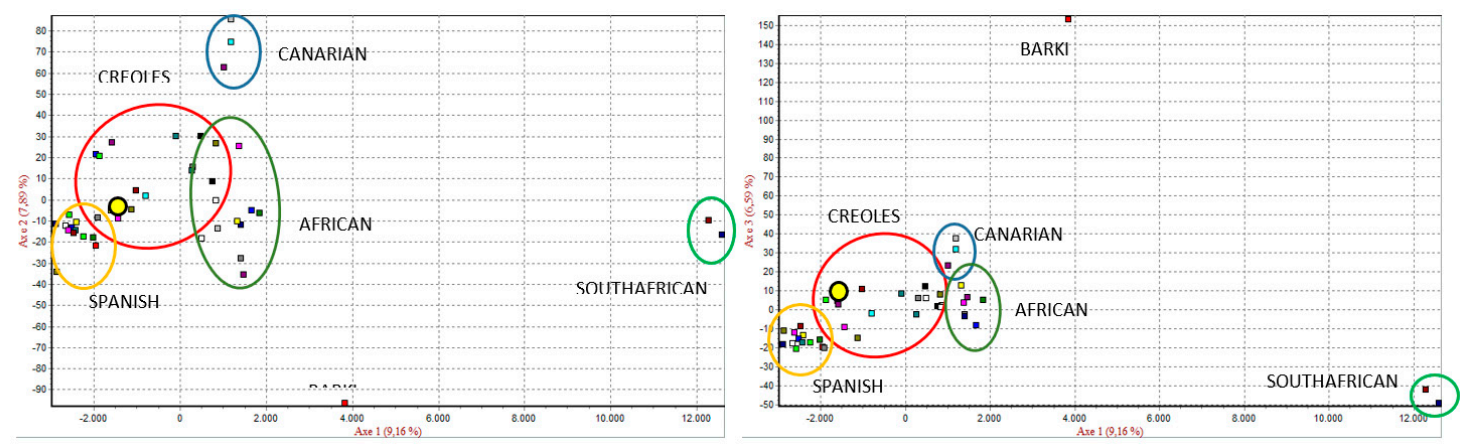

Figure 3. Correspondence Factor Analysis of 43 goat populations.

The Reynolds' genetic distance data and the $\mathrm{F}_{\mathrm{ST}}$ values between pairs of goat populations are shown in Table S1. The values for the Chusca Lojana goat are highlighted in gray, showing the lowest values of genetic distance with the other Creole goats (0.03-0.11) and the largest distance with the Galapagos goat (0.18) and the South African goats (Kalahari, 0.15; and Boer, 0.18).

In the graphic representation of Reynolds' genetic distances in a network dendrogram (Figure 4), it can be observed that the Chusca Lojana and the Galapagos Islands breeds share similar origins with the Bolivian Creole Goats.

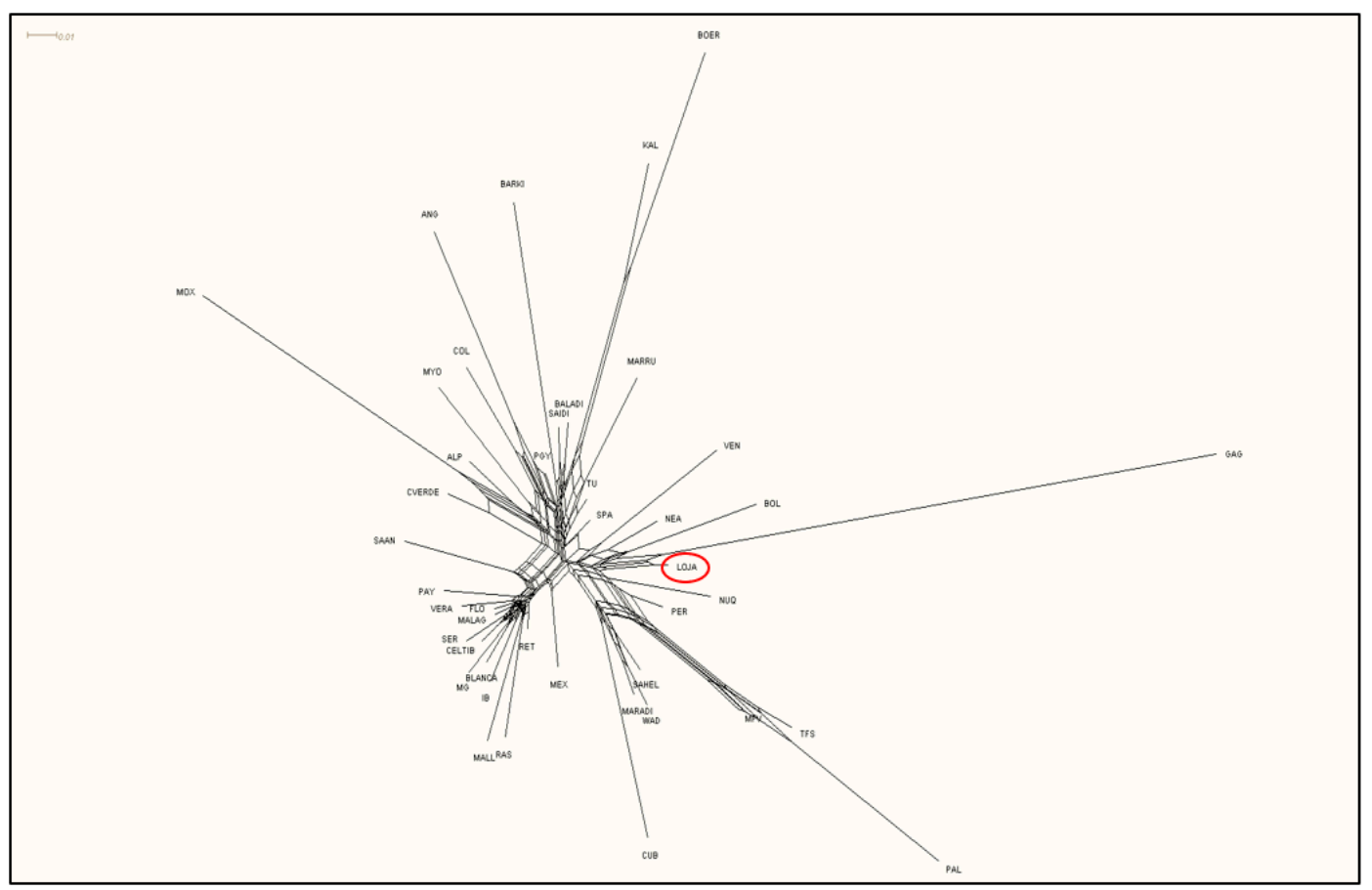

Figure 4. Neighbor-Net representation of Reynolds' genetic distances between 43 goat populations. 
Shown graphically in Figure 5 is the population structure of the 43 goat populations using STRUCTURE v.2.1 software. Every individual is represented by a vertical bar and each color is a uniform proportion of the corresponding cluster. When the number of estimated populations is 2 $(\mathrm{K}=2)$, data are separated in two clusters, in which one group corresponds to the European breeds (Spanish, Saanen, and Alpine) and most of the Creole breeds (shown with red), and the other group includes the African and Canary Islands breeds (shown with green). When $\mathrm{K}=5$, the breeds are separated into several clusters, such as the Spanish, the Canary Islands, and the African breeds. When $\mathrm{K}=18$, the Chusca Lojana goat is separated from the other Creole goat populations. Statistically, the optimal number of populations is $\mathrm{K}=25$. There is no subdivision or substructure of the Chusca Lojana goat when $\mathrm{K}>18$. From $\mathrm{K}=2$, more than $80 \%$ of the analyzed individuals are assigned to a single cluster.

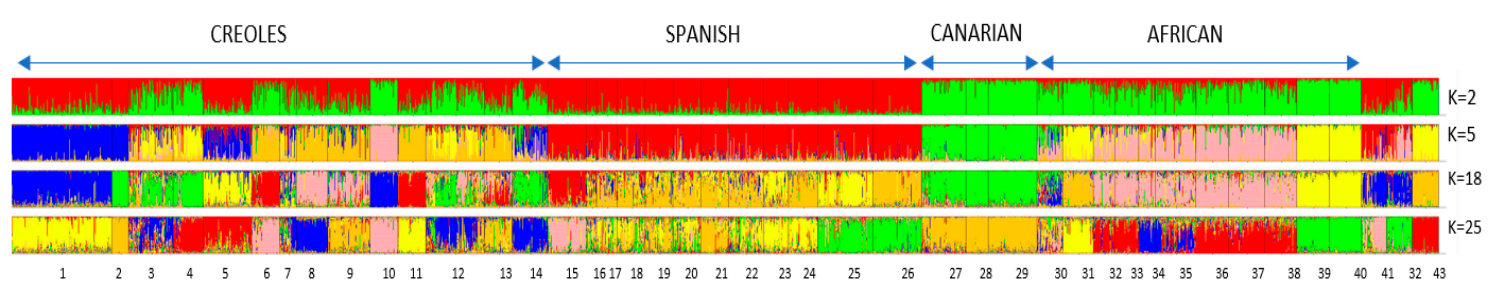

Figure 5. Genetic structure of the 43 goat populations analyzed. Graphical representation of clusters when $\mathrm{K}=2, \mathrm{~K}=5, \mathrm{~K}=18$, and $\mathrm{K}=25$. 1: Chusca Lojana; 2: Galapagos goat; 3: Spanish goat; 4 : Myotonic; 5: Mexicana; 6: Creole from Cuba; 7: Creole from Colombia; 8: Creole from Venezuela; 9 : Creole from Perú; 10: Moxotó; 11: Creole from Bolivia; 12: Creole from Paraguay; 13: North-east creole; 14: Neuquina; 15: Blanca de Rasquera; 16: Retinta; 17: Verata; 18: Blanca Andaluza; 19: Celtibérica; 20: Malagueña; 21: Murciano-Granadina; 22: Florida; 23: Payoya; 24: Negra Serrana; 25: Pitiusa; 26: Mallorquina; 27: Majorera; 28: Palmera; 29: Tinerfeña; 30: Cabo Verde; 31: Barki; 32: Baladi; 33: Saidi; 34: Morocco; 35: Tunisian Local Goat; 36: Maradi; 37: West African Dwarf; 38: Sahel; 39: Kalahari Goat; 40: Boer; 41: Saanen; 42: Alpina; 43: Anglo-Nubiana.

\section{Discussion}

The characterization process is the first step of the zoogenetic resources conservation programs. So, studies of this nature are generally recommended to save locally adapted breeds from extinction [23].

The high genetic diversity of the Chusca Lojana breed is demonstrated by the mean number of alleles (MNA $=8.3$ ) and the effective number of alleles (Ae $=4.3$ ). These values are similar to those obtained for the Spanish goat of the USA (7.81 and 4.24, respectively) and higher than those of the Creole goats of Argentina, Bolivia, Brazil, Colombia, Cuba, Peru, and Venezuela (MNA = 5.24-6.81; $\mathrm{Ae}=2.61-3.87)$. It is noteworthy that the Galapagos Creole goat displayed lower MNA and Ae values (MNA $=3.05$, Ae $=1.98)$, and the Creole Goat of Paraguay showed higher MNA and Ae values (8.71 and 5.19, respectively) [24].

The Chusca Lojana breed exhibited higher expected $(\mathrm{He}=0.71)$ and observed heterozygosity values $(\mathrm{Ho}=0.63)$ than the mean of the corresponding values for the other American Creole goat populations $(\mathrm{He}=0.638$, $\mathrm{Ho}=0.585)$. The only exception was the Paraguayan Creole, which showed higher He and Ho values [24]. The genetic diversity of the Chusca Lojana breed is similar to that reported for animals from the Central and Eastern Mediterranean (He $=0.737$ and Ho $=0.663)$ [25], but slightly higher than the diversity manifested in native breeds of the Iberian Peninsula $(\mathrm{He}=0.65$ and $\mathrm{Ho}=0.61$ ) [26] and in 71 populations in Africa and America (MNA =6, He = 0.64 and Ho =0.6) [27]. The $\mathrm{F}_{\mathrm{IS}}$ value of the Chusca Lojana breed was significant (0.1098) and higher than the mean of the corresponding values reported for the other American goat populations [24,27], being the values 0.083 and 0.082 , respectively. This significant $\mathrm{F}_{\text {IS }}$ value could be due to non-random mating within the breed. Significant inbreeding levels and deviations from the Hardy-Weinberg equilibrium can be shown in a short time if no measures are taken. 
Interestingly, the Chusca Lojana breed showed higher genetic diversity $(\mathrm{MNA}=8.3, \mathrm{He}=0.71$, and $\mathrm{Ho}=0.63$ ) than reported for 57 native goat breeds in Asia (MNA = 5.98, He = 0.59, and $\mathrm{Ho}=0.54)$ [28]. However, the $\mathrm{F}_{\mathrm{IS}}$ of the 57 Asian breeds was lower (0.073) and the $\mathrm{F}_{\mathrm{IT}}=0.191$ was similar to the corresponding values in the present study.

The genetic differentiation $\left(\mathrm{F}_{\mathrm{ST}}\right)$ of the Chusca Lojana breed and the other 42 Creole and transboundary breed populations was lower $\left(\mathrm{F}_{\mathrm{ST}}=0.098\right)$ than the values reported for 24 Creole and three cross-border breeds in America ([24], $\mathrm{F}_{\mathrm{ST}}=0.134$; [27], $\mathrm{F}_{\mathrm{ST}}=0.13$ ), for the Creole breeds of Asia $\left(\mathrm{F}_{\mathrm{ST}}=0.127\right)[28]$, and for the Creole goats of Cuba, comprising the Iberic and the African breeds $\left(\mathrm{F}_{\mathrm{ST}}=0.112\right)$ [29]. On the other hand, the $\mathrm{F}_{\mathrm{ST}}$ of the Chusca Lojana breed was higher than the values obtained for goats from Northern Europe and Central-Eastern Mediterranean (0.07) [25], West Asia (0.075) [30], and Africa (0.071) [31].

By graphic representation of Reynolds' genetic distances, it could be demonstrated that results in the present study are in accordance with the data previously reported [27], in which the Creole goat of Ecuador was grouped in the same cluster with the Bolivian, Venezuelan, Northwest Argentinian, and Peruvian goats. However, that is not the case in the results described by [24], in which the Ecuadorian goat was found to be genetically related to the Anglo Nubian, Colombian, and Paraguayan breeds, but unrelated to the Galapagos and the Bolivian goats. Therefore, it is likely that the Creole goat population studied by [24] do not correspond to the goat population Chusca Lojana.

Finally, both the work carried out by [27] and the present study evaluated similar populations and represented their population structure graphically using the STRUCTURE program. As a result of the analyses of genetic dispersion by mean of the geographic cluster model, the origins of several groups of goat breeds, such as the Iberic, Canarian, African, and American Creole, were confirmed. Accordingly, the latter is ancestrally related to the Iberian and African goat breeds.

\section{Conclusions}

The Chusca Lojana goat breed exhibits a high genetic diversity, with a heterogeneous structure inside the population; but, the existence of four different biotypes empirically admitted inside the breed was not supported by our genetic results. The Chusca Lojana breed belongs to the genetic group of the American Creoles, descendants of the of the Iberian populations imported by the Spanish colonizers five centuries ago. No genetic introgressions from the most important international breeds (i.e., Saanen, Alpina, Anglo-Nubian, African, and/or Spanish breeds) were detected in the Chusca Lojana breed.

The Chusca Lojana breed is a valuable zoogenetic resource, well adapted to its difficult environment; its conservation and selection should be encouraged, and actions should be taken to avoid future genetic erosion.

Supplementary Materials: The following are available online at http://www.mdpi.com/2076-2615/10/6/1026/s1, Figure S1: Genotyping of 8 microsatellites using Genotyper 3.7NT software, Table S1: Reynolds' genetic distances (below the diagonal) and the FST (above the diagonal) between pairs of populations.

Author Contributions: Conceptualization, L.A.-R.; methodology, L.A.-R. and T.M.-T.; validation, A.M.-M., J.V.D.-B. and L.A.-R.; software, A.M.-M.; formal analysis, A.M.-M., J.V.D.-B. and L.A.-R.; investigation, L.A.-R., T.M.-T., O.A.-B., A.F.-G. and O.C.-E.; data curation, L.A.-R. and M.Q.-P.; writing-original draft preparation, L.A.-R. and M.Q.-P.; writing — review and editing, L.A.-R., A.M.-M. and J.V.D.-B.; project administration, L.A.-R.; funding acquisition, L.A.-R.; genetic database, B.C. All authors have read and agreed to the published version of the manuscript.

Notes: ${ }^{4}$ List of the members of the BioGoat Consortium: T. Adebambo, University of Agriculture Abeokuta, Nigeria; L.A. Alvarez Franco, Universidad Nacional de Colombia, Sede Palmira, Colombia; M. Amills, CRAG, Universitat Autònoma de Barcelona, Spain. J.A. Aranguren, Universidad de Zulia, Maracaibo-Zulia, Venezuela; D.O Bedotti, INTA, EEA Anguil “Ing. Agr. Guillermo Covas”, Argentina; E. Chacón, Universidad Técnica de Cotopaxi. Ecuador; M.A. Domínguez Martínez, Universidad Autónoma Benito Juárez de Oaxaca. México; S. Dunner, Universidad Complutense de Madrid, Spain; A. Elbeltagy, APRI, Ministry of Agriculture, Cairo, Egypt; A. Galarza, Universidad Mayor de San Simón, Cochabamba, Bolivia; N. Gómez Urviola, ONG CEIN-PUNO. Puno. Perú; J. Jordana, Universitat Autònoma de Barcelona. Spain; M.R. Lanari, INTA EEA, Bariloche, Argentina; A. Manunza, CRAG, Universitat Autònoma de Barcelona, Spain; R. Martínez, Universidad Nacional de Asunción, Paraguay; P.M. Parés i Casanova, Universitat de Lleida. Spain; A. Pons Barro, SEMILLA, Islas Baleares, Spain; 
M.A. Revidatti, Universidad Nacional del Nordeste, Argentina; M.N Ribeiro, Universidade Federal Rural de Pernambuco, PE, Brasil; A. Abu Shady, Ain Shams University. Cairo, Egypt; B. Seguí, Consejería de Medio Ambiente, Gobierno Balear, Spain; P. Sponenberg, Virginia-Maryland Regional College of Veterinary Medicine, Virginia Tech, USA; A. Stemmer, Universidad Mayor de San Simón, Cochabamba, Bolivia; Oriol Vidal, Universitat de Girona, Spain.

Funding: This research was funded by Universidad Nacional de Loja (UNL)—Dirección de Investigaciones, grant number 07-DI-FARNR-2019 by the Project proposal "Estudio de la cabra Chusca Lojana con fines de selección, conservación y mejora genética en el Bosque Seco de la Provincia de Loja".

Acknowledgments: The authors appreciate the financial support provided by the National University of Loja and the assistance of the staff of technicians of MAG-Loja towards achieving the objectives of the study. A special recognition is reserved for the goat farmers in the Dry Forest region of the Province of Loja; without their cooperation, this research would not have been possible.

Conflicts of Interest: The authors declare no conflict of interest.

\section{References}

1. Mittermeier, R.A.; Myers, N.; Gil, P.R.; Mittermeier, C.G. Hotspots: Earth's Biologically Richest and Most Endangered Terrestrial Ecoregions; Agrupación Sierra Madre: Mexico City, Mexico, 1999; Volume 3, pp. 39-40.

2. Ladle, R.J.; Jepson, P.; Araújo, M.B.; Whittaker, R.J. Dangers of crying wolf over risk of extinctions. Nature 2004, 428, 799. [CrossRef] [PubMed]

3. Tollefson, J. One Million Species Face Extinction. Nature 2019, 569, 171. [CrossRef] [PubMed]

4. Food and Agriculture Organization of the United Nations. The State of the World's Biodiversity for Food and Agriculture; Bélanger, J., Pilling, D., Eds.; FAO Commission on Genetic Resources for Food and Agriculture Assessments: Rome, Italy, 2019; p. 572.

5. Hanotte, O.; Dessie, T.; Kemp, S. Time to Tap Africa's Livestock Genomes. Science 2010, 328, $1640-1641$. [CrossRef]

6. Ginja, C.; Cortes, O.; Gama, L.T.; Delgado, J.V.; Amills, M.; De Sousa, C.B.; Canon, J.; Capote, J.; Dunner, S.; Ferrando, A.; et al. Conservation of Goat Populations from Southwestern Europe Based on Molecular Diversity Criteria. In Sustainable Goat Production in Adverse Environments; Simões, J., Gutierrez, C., Eds.; Springer International Publishing: Basel, Switzerland, 2017; Volume 1, pp. 509-533.

7. Taberlet, P.; Valentini, A.; Rezaei, H.R.; Naderi, S.; Pompanon, F.; Negrini, R.; Ajmone-Marsan, P. Are cattle, sheep, and goats endangered species? Mol. Ecol. 2008, 17, 275-284. [CrossRef]

8. Ajmone-Marsan, P.; Colli, L.; Han, J.L.; Achilli, A.; Lancioni, H.; Joost, S.; Crepaldi, P.; Pilla, F.; Stella, A.; Taberlet, P.; et al. The characterization of goat genetic diversity: Towards a genomic approach. Small Rumin. Res. 2014, 121, 58-72. [CrossRef]

9. Dubeuf, J.-P.; Morand-Fehr, P.; Rubino, R. Situation, changes and future of goat industry around the world. Small Rumin. Res. 2004, 51, 165-173. [CrossRef]

10. Walsh, P.S.; Metzger, D.A.; Higuchi, R. Chelex 100 as a Medium for Simple Extraction of DNA for PCR-Based Typing from Forensic Material. Biotechniques 2013, 54, 506-513. [CrossRef]

11. Park, S.D.E. Trypanotolerance in West African Cattle and the Population Genetic Effects of Selection. Ph.D. Thesis, University of Dublin, Dublin, Ireland, September 2001.

12. Yeh, F.; Boylet, J. Population Genetic Analysis of Codominant and Dominant Markers and Quantitative Traits. Belg. J. Bot. 1997, 129, 157-163.

13. Belkhir, K.; Borsa, P.; Chikhi, L.; Raufaste, N.; Bonhomme, F. GENETIX 4.05, logiciel sous Windows TM pour la génétique des populations. Laboratoire Génome, Populations, Interactions 2004. (In French)

14. Raymond, M.; Rousset, F. GENEPOP (Version 1.2): Population Genetics Software for Exact Tests and Ecumenicism. J. Hered. 1995, 86, 248-249. [CrossRef]

15. Guo, S.W.; Thompson, E.A. Performing the Exact Test of Hardy-Weinberg Proportion for Multiple Alleles. Biometrics 1992, 48, 361. [CrossRef]

16. Wright, S. The Theory of Gene Frequencies. In Evolution and the Genetics of Populations; University of Chicago Press: Chicago, MI, USA, 1969; Volume 2, pp. 291-293.

17. Reynolds, J.; Weir, B.S.; Cockerham, C.C. Estimation of the Coancestry Coefficient: Basis for a Short-Term Genetic Distance. Genetics 1983, 105, 767-779. 
18. Langella, O. Populations 1.2.28. 1999. Available online: http://bioinformatics.org/populations/index.html (accessed on 26 September 2018).

19. Huson, D.H.; Bryant, D. Application of Phylogenetic Networks in Evolutionary Studies. Mol. Biol. Evol. 2005, 23, 254-267. [CrossRef]

20. Bowcock, A.M.; Ruiz-Linares, A.; Tomfohrde, J.; Minch, E.; Kidd, J.R.; Cavalli-Sforza, L.L. High resolution of human evolutionary trees with polymorphic microsatellites. Nature 1994, 368, 455-457. [CrossRef]

21. Page, R.D.M. Tree View: An Application to Display Phylogenetic Trees on Personal Computers. Bioinformatics 1996, 12, 357-358. [CrossRef]

22. Pritchard, J.K.; Stephens, M.; Donnelly, P. Inference of Population Structure Using Multilocus Genotype Data. Genetics 2000, 155, 945-959.

23. Alderson, G.L.H. Conservation of breeds and maintenance of biodiversity: Justification and methodology for the conservation of Animal Genetic Resources. Arch. Zootec. 2018, 67, 300-309. [CrossRef]

24. Ginja, C.; Gama, L.T.; Martínez, A.; Sevane, N.; Martin-Burriel, I.; Lanari, M.R.; Revidatti, M.A.; Aranguren-Méndez, J.A.; Bedotti, D.O.; Ribeiro, M.N.; et al. Genetic diversity and patterns of population structure in Creole goats from the Americas. Anim. Genet. 2017, 48, 315-329. [CrossRef]

25. Canon, J.; García, D.; García-Atance, M.A.; Obexer-Ruff, G.; Lenstra, J.A.; Ajmone-Marsan, P.; Dunner, S.; The ECOGENE Consortium. Geographical partitioning of goat diversity in Europe and the Middle East. Anim. Genet. 2006, 37, 327-334. [CrossRef]

26. Martínez, A.M.; Gama, L.T.; Bermejo, J.V.D.; Cañón, J.; Amills, M.; De Sousa, C.B.; Ginja, C.; Zaragoza, P.; Manunza, A.; Landi, V.; et al. The Southwestern fringe of Europe as an important reservoir of caprine biodiversity. Genet. Sel. Evol. 2015, 47, 86. [CrossRef]

27. Sevane, N.; Cortés, O.; Gama, L.T.; Martínez, A.; Zaragoza, P.; Amills, M.; Bedotti, D.O.; De Sousa, C.B.; Cañon, J.; Dunner, S.; et al. Dissection of ancestral genetic contributions to Creole goat populations. Animal 2018, 12, 2017-2026. [CrossRef]

28. Periasamy, K.; Vahidi, S.M.F.; Silva, P.; Faruque, M.O.; Naqvi, A.N.; Basar, M.; Cao, J.; Zhao, S.; Thuy, L.T.; Pichler, R.; et al. Mapping molecular diversity of indigenous goat genetic resources of Asia. Small Rumin. Res. 2017, 148, 2-10. [CrossRef]

29. Chacón, Y.E.; La, O.M.; Velásquez, F.J.; Pérez, J.E.; Delgado, V.; Cos, Y.; Martínez, A. Validación de los estándares raciales de la cabra criolla cubana para su registro internacional (Validation of the Racial Standards of the Cuban Creole Goat for Its International Registration). REDVET Revista Electrónica de Veterinaria 2012, 13, 1-8. (In Spanish)

30. Bulut, Z.; Kurar, E.; Ozsensoy, Y.; Altunok, V.; Nizamlioglu, M. Genetic Diversity of Eight Domestic Goat Populations Raised in Turkey. BioMed Res. Int. 2016, 2016, 1-6. [CrossRef]

31. Elbeltagy, A.R.; Naga, A.M.A.; Hassen, H.; Solouma, G.M.; Rischkowsky, B.; Mwacharo, J.M. Genetic diversity and structure of goats within an early livestock dispersal area in Eastern North Africa. Afr. J. Biotechnol. 2016, 15, 431-441. [CrossRef]

(C) 2020 by the authors. Licensee MDPI, Basel, Switzerland. This article is an open access article distributed under the terms and conditions of the Creative Commons Attribution (CC BY) license (http://creativecommons.org/licenses/by/4.0/). 